\title{
Stereotypes of Intimate Partner Violence: Do Sex and Sexual Orientation Matter?
}

\author{
María Elena Meza-de-Luna ${ }^{1}$ \\ Leonor María Cantera, \\ Josep María Blanch \\ Adriano Beiras \\ Universitat Autònoma de Barcelona
}

\begin{abstract}
This study analyzed stereotypes on intimate partner violence (IPV) of heterosexual and same-sex couples. The participants, 232 Mexican college students, evaluated physical and psychological IPV exerted by men and women with different sexual orientations. The data were analyzed using the Wilcoxon test. The results indicate that men evaluated women and gay men as having a similar IPV, while men's perceptions of IPV for these groups were higher than those of women. Women viewed heterosexual men as the most violent and evaluated the other groups with different degrees of IPV. Physical violence is regarded as natural in men, both gay and heterosexual. To conclude, the results suggest that IPV stereotypes are affected by the sex of the evaluators and by their sexual orientation. It is relevant to expand the scope of prevention programs.
\end{abstract}

Keywords: intimate partner violence, stereotyped attitudes, male female relations, male homosexuality, female homosexuality, Mexico

\section{Estereótipos de Violência de Parceiro Íntimo: O Sexo e a Orientação Sexual são Importantes?}

\begin{abstract}
RESUMO - Esta pesquisa avalia estereótipos sobre violência entre parceiros íntimos (VPI) relacionados a casais heterossexuais e homossexuais. Os/as participantes, 232 estudantes universitários mexicanos, avaliaram a VPI física e psicológica exercida por homens e mulheres com diferentes orientações sexuais. Os dados foram analisados com o teste de Wilcoxon. Os resultados indicam que homens avaliaram mulheres e homens gays como apresentando níveis similares de VPI, sendo a percepção masculina sobre VPI nesses grupos superior à feminina. Mulheres percebem homens heterossexuais como mais violentos e atribuem graus diferentes de VPI para os demais grupos. A violência física é vista como natural em homens, homossexuais ou heterossexuais. Para concluir, é possível sugerir que estereótipos de VPI são influenciados pelo sexo do avaliador e por sua orientação sexual. É relevante ampliar o alcance de programas preventivos.
\end{abstract}

Palavras-chave: violência doméstica, estereótipos, relações homem-mulher, homossexualidade, lesbianismo, México

Gender stereotypes are common in research for various reasons including pervasiveness of the issue, links regarding age, gender roles, and simply because everyone is a member of one gender or the other (Krueger et al., 2003). Stereotypes are usually negative beliefs regarding characteristics or traits shared by members of specific social groups. They create cognitive frameworks, which strongly influence the way social information is processed (Baron \& Byrne, 2005). It is a process in which people are judged and treated in a certain manner due to their membership of a social category, in which the individuals are seen as interchangeable subjects (Bodenhausen, 2005). Stereotypes are conveyed through many mediums, including: families, schools, peer groups, and the mass media in an effort to simplify complex information (see Barnett, 2006). Therefore, cultural context has an important influence on stereotypes. In this study, the intimate partner violence (IPV) adjudicated to people of a different sex and sexual orientation are examined in Mexico, where socio-historical dynamics have changed

1 Endereço para correspondência: Universitat Autônoma de Barcelona, Facultat de Psicologia, Departament de Psicologia Social, Despatx B5/040, Bellaterrra (Cerdanyola del Vallès), Barcelona, Spain, CEP. 08193.E-mail: mezamariel@yahoo.com significantly in the last three decades. Moreover, a negative correlation between stereotypes and education levels has been demonstrated (Okoye \& Obikeze, 2005; Plous \& Williams, 1995). Consequently, this study focuses on an educated sector of the population who are expected to have less stereotypical beliefs than people with lower levels of education.

\section{Socio-Historical Context}

The patterns of violence and the IPV stereotypes may be affected by the larger socio-historical context. Individuals are subject to a unique and idiosyncratic time and place, i.e., the different socio-historical context where each generation is socialized (McHugh et al., 2008). IPV stereotypes are expected to change in Mexico due to the fact that the manner in which the couples are formed and organized has been transforming in recent decades. Official statistics of the Mexican government (Instituto Nacional de Estadística, Geografia e Informática [INEGI], nd, 2000, 2003, 2005, 2007) indicate a sharp decrease in the number of married women between the ages of 15 and 19 years, from $44.9 \%$ in 1970 to $24.1 \%$ in 2008 ; the crude birth rate has decreased 
from 28.8 in 1990 to 17.8 in 2010 ; the total fertility rate has decreased from 5.7 in 1976 to 2.1 in 2010; and the crude marriage rate has also seen changes, from 7 in 1970 to 5.5 in 2008. Moreover, there has been an increase in the ratio of divorces as compared to marriages, from 3.2 in 1970 to 13.9 in 2008. Also, the average annual growth rate of femaleheaded households has increased from 1.0 in 1970 to 5.0 in 2005 and the total growth rate of single households from 0.4 between 1970-1990 to 5.7 from 1990-2000. Other important indicators include the more liberal legalization of: samesex marriage in Mexico City (Gaceta Oficial del Distrito Federal [GODF], 2009), abortion (GODF, 2007) and uterus subrogation (Asamblea Legislativa del Distrito Federal, 2010). All these factors reflect a myriad of social changes.

It has been hypothesized that the structure of the social relations leads to a clear differentiation between public and private spheres (Amoros, 1994). However, with the recent inclusion of women in spaces previously restricted to them, now the boundaries are less well defined. In the seventies, women found it very difficult to access college-level education, leading to a lack of expertise and underemployment. Usually they were solely responsible for the housework and family care, which consequently lead to economic dependence. Recently more women have had access to formal education, employment and social participation (Gonzalez, 2006). These changes impacted the family composition and the subjectivities of men and women (Gonzalez, 2006). Today women are more autonomous (Castro, Casique, \& Bridis, 2008; Tellez, 2008). In spite of this, it is still debatable whether the existence of greater equality is now present. For example, Schultz (2006) demonstrated that access to jobs did not necessarily lead to greater autonomy, empowerment and changes in the subjectivity of women. It is noteworthy that idyllic love is still present in the relationship model (Altable, 1998; Altable, 2005), which categorizes men as strong and women as weak. Therefore, even when women are gaining public spaces and are being more independent, stereotypic roles of violent behavior are not clearly defined. This is still a current debate topic.

Diekman and Eagly (2000), under the social role theory assumption that stereotypes are imprinted on a group by the behavioral role of their members, postulated that as the typical roles change on society, so the stereotypes do. Consequently, the purpose herein is to evaluate the IPV stereotypes in the present socio-historical context in Mexico, where social changes have been influencing the organization and structure of romantic relationships. Furthermore, there are in Mexico different approaches to explain the phenomena of intimate partner violence, as is discussed in the following section.

\section{Antagonist Production of IPV Knowledge}

There is a large body of research regarding IPV as exerted from males to females (Beiras \& Cantera, 2012; Blay, 2014; Beiras \& Cantera, 2014; Bonino, 2004; Flood, 2011; INEGI, 2003a, 2006; Krug, Dahlberg, Mercy, Zwi, \& Lozano, 2003; Ramírez-Rodríguez, 2006; Sánchez-Jiménez, Hernández-Trejo, \& Lartigue-Becerra, 2008, Toneli, Lago,
Beiras, \& Clímaco, 2010). In general, the incidence of emotional, physical and sexual violence from men to women has been widely investigated. In particular, some studies have offered a better understanding of male violence toward women within certain situations, such as: during pregnancy (Quelopana, Champion, \& Salazar, 2008; Sánchez-Jiménez et al., 2008); due to low-income and within youth groups (Castro et al., 2003; Quelopana et al., 2008); because of low levels of education, as a result of drug and alcohol abuse, and rape (Rivera-Rivera et al., 2004); within histories of childhood violence (Gómez \& Speizer, 2009; Rivera et al., 2004); caused by work related stress (Ortega-Ceballos et al., 2007); when a woman has a higher level of education than a man or a couple lives in one of the partner's parent's home (Castro et al., 2008); and finally, as influenced by cultural reasoning that tends to increase tolerance (Agoff, Rajsbaum, \& Herrera, 2006).

Despite the explosion of gender studies, addressing heterosexual violence from men toward women, there is a body of investigations and theories that diverge from that line of thinking. It has been stated that these studies of male violence against women are contributing to the establishment of the violent stereotypes according to gender. Therefore, for instance, since interpersonal violence is a construction where each protagonist, as sexual being, has a crucial impact, then studying wives as victims leads to the construction of wife abuse; within the couple, figures of helpless and victimized women and abusive males emerge (Izquierdo, 2001; McHugh $\&$ Frieze, 2006). For over three decades, the studies of family violence have demonstrated evidence of violence from both members of heterosexual couples (Regan, et al., 2006; Steinmetz, 1977; Straus 1979). Moreover, evidence confirms violence goes beyond gender roles andis present in same-sex couples and not only the male abusing the woman, but in the other direction too, women being abusive toward men (Cantera-Espinosa 2004a; Cantera-Espinosa, 2004b; Mezade-Luna, 2010; Meza-de-Luna \& Cantera-Espinosa 2008).

Nevertheless, the traditional family violence theory has been criticized. More complex models than simply counting the numbers of cases of violence have been proposed. For instance, Saunders (1988) has been advocating for the inclusion of the reasons and the physical consequences of those incidents. Moreover, it has been suggested to address the topic with the inclusive-gender with systemic and multiple-causal factors (Hamel, 2007), where the violence is seen as a human problem. In this sense, postmodernist socio-historical context depicts violence as something common to any human being, not exclusive to men (Beiras \& Cantera, 2014). For McHugh and Frieze (2006) femaleinitiated or mutual violence may be more common among younger woman. One interpretation is that postfeminist young women see violence as gendered-neutral behavior. For instance, young women and men in the United States were raised in an era of television viewing and video games, presenting figures of aggressive women, that were not a part of the formative education of people over 50 years old (Dill \& Thill, 2007). There is the possibility that IPV stereotypes are changing due to the influence of the socio-historical contexts where the figure of violent women might be more commonly accepted, or women's violence could be more 
evident in diverse situations such as: a worker, couple, friend, mother, etc.

Usually, stereotypical thinking reflects a variety of cognitive and motivational processes (Hilton \& Hippel, 1996). Stereotypes have the function of making the processing of information easier by associating new incoming information within previously constructed and stored knowledge. Evidence has demonstrated that previous knowledge can shape the stereotypes (Aronson, Fried, \& Good, 2002; Good, Aronson, \& Inzlicht,, 2003; Mason, Kahle, \& Gardner, 1991; Spencer, Steele, \& Quinn., 1999). Consequently, the different types of studies and theories can influence the stereotypes, as cognitive frames. Since the growing evidence regarding IPV has been presented in antagonistic direction, the objective of these researchers is to evaluate IPV stereotypes. Furthermore, some studies make stereotypes of a specific group within the population visible, with a bias regarding the amount of information on the phenomenon that is produced. For example, racism's studies have proliferated showing the negative stereotypes of white people over black people, but neglects the stereotypes that black people can have in relation to whites and other races (Nunnally, 2009). The objective of this study is to assess the stereotypes that men and women have, not only about heterosexual IPV in the direction of men toward women, but also about how violence is seen within same-sex couples and in both directions for heterosexual couples, as well as to evaluate the possible differences on IPV stereotypical perceptions between men and women. Therefore, the question for this investigation was posed: Do college students perceive differences in the amount of IPV's when evaluating men and women in gay, lesbian or heterosexual relationships? And, are there any stereotypical differences between men and women?

\section{Hypotheses}

Departing from the tendency to perceive men's violence as natural and normal (Cantera-Espinosa, 2004b), the following hypotheses in reference to physical and psychological IPV has been set forth as follows:

(a) A heterosexual man (HM) will be perceived as more violent than a heterosexual woman (HW).

(b) A HM will be perceived as more violent than a lesbian woman (LW).

(c) A HM will be perceived as more violent than a gay man (GM).

(d) A GM will be perceived as more violent than a HW.

(e) A GM will be perceived as more violent than a LW.

(f) A LW will be perceived as more violent than a HW.

\section{Method}

This study was carried out to better understand the IPV stereotypes within different and same sex couples in the actual socio-historical context. The perception regarding the degree of violence that a man or woman can exert on their romantic relationships, whether this be heterosexual, gay or lesbian, was evaluated. A questionnaire for evaluating the perception in four directions of violence in relation to physical and psychological IPV was drawn-up.

\section{Participants}

The participation criteria for the sample selection included: participants should be Mexican, resident in the urban area of Queretaro, Mexico, over the age of 18 and a minimum of a high school level education. A total of 232 Mexican undergraduate students participated, consisting of 165 women, 63 men, 4 not self-identified. They ranged from ages 18 to $58(M=21.3, S D=4.0)$. The participants identified their sexual orientations as: 222 heterosexual, 95.7\%; 0 lesbian, $0 \% ; 2$ gay, $0.9 \%$; 2 other, $0.9 \%$; and 6 that did not indicate their sexual orientation, 2.6\%. Part of the participant sample included college students from the faculties of business, law, veterinary, nutrition, psychology, and arts.

\section{Instrument}

A specific purpose questionnaire was developed by our investigation team to evaluate two IPV's types; physical and psychological, in four possible IPV's direction according to the executor (HM, HW, GM and LW). Consequently, in the questionnaire, the participants were asked to give their opinion about how many physical IPV (hitting, pushing, etc.) and psychological IPV (humiliation, insults, threats, verbal intimidation, emotional blackmail, etc.) they believed exist in the following couples: (a) Heterosexual - violence from men toward women, (b) Heterosexual - violence from women toward men, (c) within Gay relationships, and (d) Lesbian relationships. Perceptions of violence were assessed on scales ranging from $1-7,1$ indicating very little violence and 7 indicating a lot of violence. The questionnaire had eight questions; four of them for physical violence (one for each sex and sexual orientation, as described previously) and four for psychological violence. The participants also completed a demographic questionnaire which included age, gender, sexual orientation, education, socio-economic status, and marital status.

\section{Procedure}

The participants were recruited from different classes of university courses, after the general objective of the investigation was presented. Places, days and times of participation were flexible to accommodate the participants. The participants completed a questionnaire via computer. 
Data was compiled utilizing specific purpose software, that had been specially developed for the research team.

Statistical data analysis was done with SPSS PC 12.0 tools. For physical and psychological IPV's the following analysis was carried out: (a) A descriptive statistical analysis; (b) A Wilcoxon test for independent samples was used to evaluate similarities between the perceptions of men and women; (c) Paired samples of Wilcoxon Signed-ranks tests were used for the total sample to ascertain if the hypotheses were valid; and (d) a Wilcoxon Signed-ranks test was used to compare two sets of scores among all possible combinations within physical and within psychological IPV. For example, in order to assess if the perception of men regarding physical IPV exerted by HM was different from the one done by HW, GM or LW; we made three comparisons of the scores: HM-HW, HM-GM and HM-LW. A significance level of 0.05 was established to prevent the null hypothesis and to assist theinvestigators to assess the similarities between groups.

\section{Results}

In the total sample, physical and psychological IPV incidents, on average, were generally rated higher in men's relationships. The prevalence was perceived in the following descending order of importance: $\mathrm{HM}>\mathrm{GM}>\mathrm{LW}>\mathrm{HW}$, see Figure 1.

However, women and men have different perceptions about who is exerting more IPV (according to sex and sexual orientation). Women have a tendency to perceive IPV with the

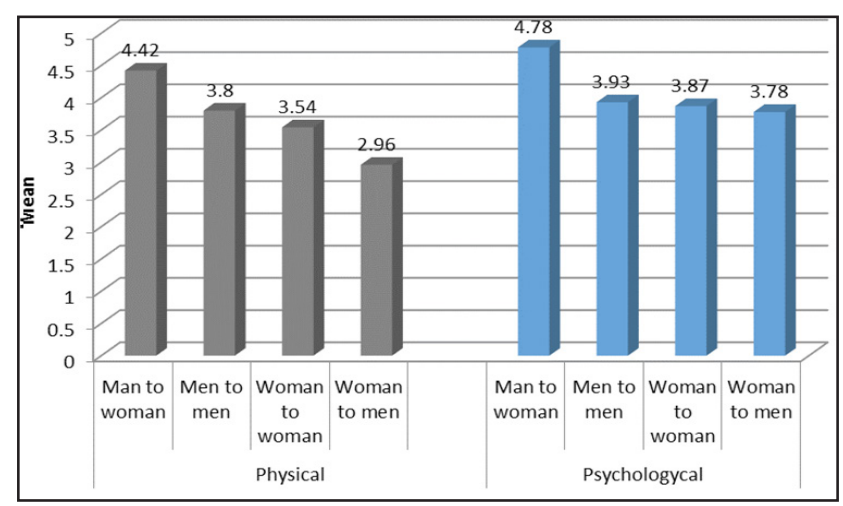

Figure 1. Perception of physical and psychological intimate partner violence, according to sex and sexual orientation. The results presents the mean scores, evaluated from 1 to $7(1=$ very little violence and $7=\mathrm{a}$ lot of violence). following order: $\mathrm{HM}>\mathrm{GM}>\mathrm{LW}>\mathrm{HW}$. However, within the men's group, on average, participants were of the opinion that IPV prevalence was GM $>\mathrm{HM}>\mathrm{LW}>\mathrm{HW}$ (see Figure 2). We found a statistically significant difference between men and women suggesting that they perceive differently physical IPV for the HM, HW, and GM; in fact, men have a tendency to perceive more favorable to HM, and women to HW and GM (see Figure 2 and Table 1). However, there is no-difference among genders' perception of IPV exerted by lesbians. In relation to the psychological IPV, there is evidence that men and women disagree when assessing IPV for HM and GM, but there is not a significant statistical difference for $\mathrm{HW}$ and LW (see Figure 2 and Table 1).

Paired comparisons of different IPV's directions were made in each of the three groups: the total sample, men and women. The paired Wilcoxon Signed-ranks test results are shown in Table 2. The results for the physical IPV demonstrate that in the total sample and the women's group this was assessed as different in all types of couples; meaning that there is a different perception that physical IPV is exerted differently according to the sex and sexual orientation. Significant differences were found in how men evaluated physical IPV in HW with respect to HM, GM or LW, and between GM and LW, but not between HM as compared with GM or LW. For the psychological IPV, in the entire sample and in the women's group there were significant differences

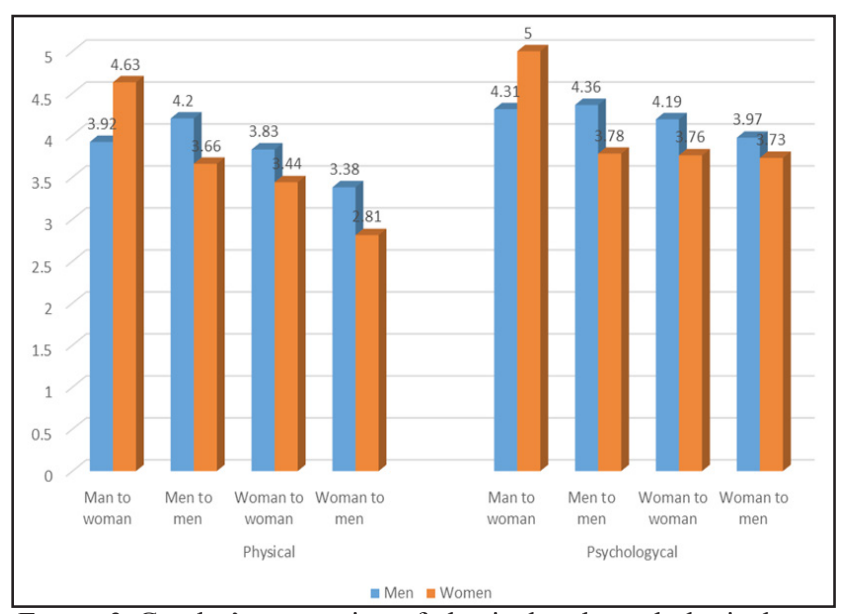

Figure 2. Gender's perception of physical and psychological intimate partner violence, according to sex and sexual orientation. The results presents the mean scores, evaluated from 1 to $7(1=$ very little violence and $7=$ a lot of violence $)$

Table 1. Gender's Perception of Physical and Psychological Intimate Partner Violence

\begin{tabular}{ccccc}
\hline \multirow{2}{*}{$\begin{array}{c}\text { IPV } \\
\text { exerted by: }\end{array}$} & $\begin{array}{c}\text { Men's perception } \\
\text { Mean (SD) }\end{array}$ & $\begin{array}{c}\text { Women's } \\
\text { perception Mean } \\
\text { (SD) }\end{array}$ & $\begin{array}{c}\text { Men's perception } \\
\text { Mean (SD) }\end{array}$ & $\begin{array}{c}\text { Women's } \\
\text { perception Mean } \\
\text { (SD) }\end{array}$ \\
\cline { 2 - 5 } Man to woman & $3.92(1.49)$ & $4.63(1.59)^{* *}$ & $4.31(1.63)$ & $5.00(1.76)^{* *}$ \\
Woman to men & $3.38(1.47)$ & $2.81(1.27)^{* *}$ & $3.97(1.64)$ & $3.73(1.51) \mathrm{ns}$ \\
Men to men & $4.2(1.42)$ & $3.66(1.51)^{* *}$ & $4.36(1.35)$ & $3.78(1.54)^{*}$ \\
Women to women & $3.83(1.48)$ & $3.44(1.62) \mathrm{ns}$ & $4.19(1.61)$ & $3.76(1.65) \mathrm{ns}$ \\
\hline
\end{tabular}

Notes. The results presents the mean scores, evaluated from 1 to $7(1=$ very little violence and $7=$ a lot of violence). Where $S D=$ Standard deviation; $*=p<.05 ; * *=p<.001$ and $n \mathrm{~s}=$ no significant. 
regarding their perceptions when HM violence was compared with HW, GM or LW, but not between HW and GM or LW, or between GM and LW. Furthermore, the men's group did not estimate significant psychological IPV differences in any pairs of cases (see Table 2).

Table 2. Paired Comparison of IPV'S Direction by Total Sample and Gender

\begin{tabular}{ccccc}
\hline \multirow{2}{*}{ IPV' Type } & Comparison & \multicolumn{3}{c}{ Sample } \\
\cline { 2 - 5 } & & Total & Men & Women \\
\hline Physical & HM-HW & $-9.21^{* *}$ & $-2.20^{*}$ & $-9.01 * *$ \\
& HM-GM & $-4.77^{* *}$ & $1.15 \mathrm{~ns}$ & $-5.96^{* *}$ \\
& HM-LW & $-5.74 * *$ & $0.40 \mathrm{~ns}$ & $-6.08^{* *}$ \\
& HW-GM & $-6.37 * *$ & $-3.25 * *$ & $-5.40^{* *}$ \\
& HW-LW & $-4.95^{* *}$ & $-2.10^{*}$ & $-4.43^{* *}$ \\
& GM-LW & $-3.29 * *$ & $-2.39^{*}$ & $-2.48^{* *}$ \\
& HM-HW & $3.00^{* *}$ & $-1.81 \mathrm{~ns}$ & $-7.07 * *$ \\
& HM-GM & $-5.98^{* *}$ & $-0.15 \mathrm{~ns}$ & $-6.61 * *$ \\
& HM-LW & $-5.89 * *$ & $-0.79 \mathrm{~ns}$ & $-6.06^{* *}$ \\
& HW-GM & $-1.09 \mathrm{~ns}$ & $-1.54 \mathrm{~ns}$ & $-0.29 \mathrm{~ns}$ \\
& HW-LW & $-0.68 \mathrm{~ns}$ & $-0.95 \mathrm{~ns}$ & $-0.11 \mathrm{~ns}$ \\
& GM-LW & $-1.39 \mathrm{~ns}$ & $-1.69 \mathrm{~ns}$ & $-0.63 \mathrm{~ns}$ \\
\hline
\end{tabular}

Notes. The results presents the mean scores, evaluated from 1 to 7 (1 $=$ very little violence and $7=$ a lot of violence). Where $S D=$ Standard deviation; $*=p<.05 ; * *=p<.001$ and $n \mathrm{~s}=$ no significant.

\section{Discussion}

First, the concordances of the results will be discussed. This study has revealed that there is evidence that the participants felt IPV's are present for all sexes and sexual orientations. Even when stereotypes are evident, it should be emphasized that the evaluation is not ranked on the upper end of the scale, that of $7=$ a lot of violence, but somewhere in the middle rank, at approximately 4.Consequently, in the sample, the IPV is generally recognized as something present in the life of each couple, and not as a minor prevalence. These results indicate the social perception of the IPV as a common factor of any couple, not just for heterosexuals from men to women. It appears that violence is perceived as something that occurs and is not dependent on sex or sexual orientation. Arguably, the perspective of this social group should be taken in consideration into diverse fields: Academically; appeals to investigate IPV in broad manner, transcending the heterosexual couple and direction of man to woman. Second, in a practical sense, it imposes a question to social action and programs addressing women's mistreatment, which in Mexico is common; justifying the need to increase prevention programs dealing with the violence that people, as humans, may receive and do, and not only on the basis of sex or sexual orientation.

Furthermore, there is evidence regarding four coincidences in the perception of IPV between men and women: (a) HW are the least physical violent as compared with HM, GM and LW, see Table 1 ; (b) GM are more physical violent in their relationships than LW, see Table 1; (c) both groups have a significant agreement regarding the degree of physical and psychological violence exerted by LW, see Table 1; (d) there is agreement in the psychological violence of $\mathrm{HW}$, see Table 1 .

Focusing on the divergences, the comparison between all pairs of IPV's cases within the total sample leads to different conclusions for the hypotheses concerning both types of violence. For physical IPV, men are seen with stronger negative stereotypes than women, see Table 1. Specifically, this stereotype for men is even worse for HM than GM and the most benevolence is in relation to HW. For the psychological IPV, the same stereotype is maintained for the HM which is seen as the most violent. However, LW, GM and HW are seen as similar. Consequently, in first instance, the results appear to confirm the hypotheses about physical IPV. And the psychological IPV's hypotheses, that HM are seen as more violent compared to others, but not as with the rest of the assumptions where the HM is excluded. However, these results should be interpreted with caution, since they are biased by perception in the women's group which was 2.6 times the size of the men's group. The comparative relations of both groups and the analyses of each individual group are more compelling and should be given special consideration.

Comparing the responses between men and women it was found that there are differing opinions about the degree of IPV perceived in various directions. Women and men disagree about the existence and amount of IPV they believe to be present from HM to HW and between gay men, see Table 1. In fact, for the physical and psychological IPV, women ranked these as higher for HM than men did; 0.71 and 0.69 , respectively. Also men evaluated GM higher than women did; 0.54 and 0.58 , respectively. In addition, both groups considered the physical IPV exerted from HW to HM differently. The men accessed 0.57 more points than women did. Therefore, even when both groups perceive $\mathrm{HM}$ as more violent than HW, they do not do so to the same degree. Also, despite the consensus that women are the least violent in any of their relationships, especially HW, women ranked this as more evident than men did. As a result, there is an in-group phenomenon in both IPV's types; where each gender discriminates favorably within their group than outside their group. For instance, for the physical IPV, the women's group demonstrated that they believe the worst violence is that exerted from HM to $\mathrm{HW}$, with 1.82 more points assessed than vice-versa. While men gave 0.54 points of differentiation, see Table I. The same tendencies were noted for the psychological IPV.

This study demonstrates evidence regarding the differences of opinions for men and women, as individual groups, while stereotyping is still present. Women tended to assess HM as the most violent compared with any others. At the same time, in the case of physical IPV, HW were seen by women as the more vulnerable group and least violent. Consequently, they have less negative physical IPV stereotypes for HW, then for LW, followed by GM, and finally HM. On the other hand, in general, when comparing the responses of men's group for the physical IPV, they believed that HW were the least violent; and, their assessment about HM was not significantly different from the ones exerted by GM or LW, even though GM were evaluated greater than LW. 
In other words, men tend to see themselves as somewhere in the middle of the scale determining violence between GM and LW, where the slight differences between HM and GM or LW made a significant difference in regards to GM and LW. The responses for the psychological IPV demonstrated certain differences between men and women as individual groups. Men did not evaluate a significant difference regarding any psychological IPV as compared to the others, but did give higher rankings to GM than women. While women have the strongest negative stereotype for HM, they do not see a significant difference for GM, LW and HW. Consequently, men were inclined to believe that everybody participates in psychological IPV to a similar degree, but women tent to judge HM severely. Nonetheless, men and women agreed on the degree of violence of HW and LW. This evidence suggests the general consciousness and acceptance of women exerting a moderated degree of psychological IPV close to 4. This draws attention the fact that women are perceived, by themselves and men, as being capable of doing more psychological than physical IPV. Both groups agree on the degree of psychological IPV exerted by women.

Therefore, for the physical IPV was seen as consistent with previous research (Seelau \& Seelau, 2005). Both groups demonstrated a pattern of judgments consistent with genderrole stereotypes; perceiving HM as more physical violent than HW, and HW as more vulnerable. These differences are related to both sexes and may suggest that the patriarchal model should be seen as still prevalent. Patriarchal power is present through all the social organizations and it influences the way each person thinks about him/herself and takes a position according to that sex and gender system (Bui \& Morash 2008; Hunnicut, 2009; Lee \& Hadeed, 2009; Lindhorst \& Tajima, 2008); the power inequalities and established unbalance by which men tend to dominate women. Moreover, even when within a same-sex couple this is expected to be more "equal" in context than in the heterosexual couples, men and women appeared to believe that GM are more physical violent than LW. Consequently, confirming that men are thought to be capable of using more physical IPV's than women, regardless of sexual orientation. Therefore, the naturalization of men's physical violence is present. The stereotypes for the psychological IPV concur with previous studies in Mexico (INEGI, 2006) which reveals that psychological violence is more prevalent than the physical.

The dissimilar stereotypes among men and women address different implications. Academically, these facts suggest taking into account the participant's sex in research projects, and being aware of the bias that these stereotypes might influence their responses. For instance, when analyzing opinions regarding IPV within a specific sex. Secondly, the presence of IPV stereotypes has social and political implications. For example, when an IPV case is mediated by authorities, such as the police or court system, there might be a tendency to be biased by: (a) Authority's sex of the person who is judging; (b) the sex and sexual orientation of those receiving or exerting the IPV, (c) whether the violence is physical or psychological. Therefore, when a person, other than HW, is seeking legal aid related with IPV, stereotypes can interfere as they may not be perceived equally. They could be minimized, overlooked or not believed to exist. This is crucial to the manner social agents make decisions about the phenomena, for example: health care departments, psychological aids, social support nets including family, friends, and in general each person as individual.

In conclusion, this study has shown evidence of different physical and psychological IPV stereotypes, between men and women, when evaluating persons of diverse sex and sexual orientation. There is a tendency for men to implement these stereotypes more frequently than women for either type of IPV, in all directions, except HM. However, women, even when evaluating physical and psychological violence of $\mathrm{HW}$, GM and LW as less prevalent, establish a differentiation between them, and have a stronger negative IPV stereotype for HM than men. The original hypotheses for the physical IPV were observed to be correct for the women group.

Since the women are seen, by men and women, as less physically violent than men. The physical hypotheses concerning women were also confirmed, regardless of the sexual orientation of women. Also, the hypothesis that LW is expected to be more violent than HW was confirmed. However, for the men's group there is a perception that physical IPV of HM is similar to that of GM or LW. Consequently, this part of the hypotheses has been rejected. The hypotheses of the psychological IPV stereotypes are accepted for the women's group when the HM is involved, but not in the other cases, nor for the men's group; for these, the stereotypes were evaluated as equal.

Taken as a whole, the results offer an idea of IPV perception as being an important prevalence in any couple, which should be taken into consideration when addressing the relevance of prevention into a wider scope. Moreover, the evidence of the different IPV stereotypes, between men and women, broadens the awareness of the possible bias that can be aroused in social, political, and academic decisions, when dealing with specific IPV cases, depending on who decides and about whom.

It is also important considered this study may have some limitations because of the difference of sampling heterosexual women and heterosexual men. This can bring some significant differences due to gender issues, bringing different perceptions onto the subject. This question may partly compromise the results. Further study would be needed to better explore these differences, based on the study in this research. Also, in future researches, it suggests deep analysis about the difference of perception of gays and lesbians about IPV is needed.

\section{Future Investigation}

Deeper qualitative investigation is recommended in order to better understand: (a) how people explain themselves in regard to these stereotypes of same sex relationships, where both members have similar gender acculturation and access to power, yet could not have the same inequalities as typically found in heterosexual couples; (b) why the stereotype evaluation is close to the middle of the scale; and (c) if stereotyping is different in people of different ages and, if so, to what degree and why. Finally, it may be of interest to proceed with a similar study, focusing on same-sex communities in order to ascertain a larger representation of GM and LW opinions. 


\section{References}

Agoff, C., Rajsbaum, A., \& Herrera, C. (2006). Perspectivas de las mujeres maltratadas sobre la violencia de pareja en México. Salud Pública de México, 48(2), 307-314.

Altable, C. (1998). Penélope y las trampas del amor (2nd ed.). Madrid, Spain: NUA Libres.

Altable, C. (2005). Modelos amorosos que matan. Eliminar obstáculos para alcanzar la igualdad. Fundación Isonomía Universitat Jaume I, 1(12), 157-165.

Amoros, C. (1994). Espacio público, espacio privado y definiciones ideológicas de lo masculino y lo femenino. In C. Amoros (Ed.), Feminismo, igualdad y diferencia (pp. 23-52). Ciudad del México: UNAM, PUEG.

Aronson, J., Fried, C. B., \& Good, C. (2002). Reducing the effects of stereotype threat on African American college students by shaping theories of intelligence. Journal of Experimental Social Psychology, 38(2), 113-125. doi; http://dx.doi.org/10.1006/ jesp.2001.1491

Asamblea Legislativa del Distrito Federal. (2010). Aprueba $A L D F$ ley de gestación subrogada en el DF. Retrieved from http://www.aldf.gob.mx/comsoc-aprueba-aldf-ley-gestacionsubrogada-df--6818.html

Barnett, B. (2006). Medea in the media: Narrative and myth in newspaper coverage of women who kill their children. Journalism, 7(4), 411-432. doi: 10.1177/1464884906068360

Baron, R., \& Byrne, D. (2005). Psicología Social. Madrid: Pearson Education and Prentice Hall.

Beiras, A., \& Cantera, L. (2012) Narrativas personales, construcción de masculinidades - aportaciones para la atención psicosocial a hombres autores de violencia. Psico, 43(2), 251-259.

Beiras, A., \& Cantera, L. M. (2014). Feminismo pós-estruturalista e masculinidades: Contribuições para a intervenção com homens autores de violência contra mulheres. In E. A. Blay (Ed.), Feminismos e masculinidades. Novos caminhos para enfrentar a violência contra a mulher (pp.29-43). São Paulo: Cultura Acadêmica.

Blay, E. A. (2014). Feminismos e masculinidades. Novos caminhos para enfrentar a violência contra a mulher. São Paulo: Cultura Acadêmica.

Bodenhausen, G. V. (2005). The role of stereotypes in decisionmaking processes. Medical Decision Making, 25(1),112-118. doi: 10.1177/0272989X04273800

Bonino, L. (2004). Las microviolencias y sus efectos: Claves para su detección. In C. Ruíz-Jarabo \& P. Blanco (Eds.), La violencia contra las mujeres. Prevención y detección, cómo promover desde los servicios sanitarios relaciones autónomas, solidarias y gozosas (pp. 83-100). Madrid: Dimas de Santos.

Bui, H., \& Morash, M. (2008). Immigration, masculinity, and intimate partner violence from the standpoint of domestic violence service providers and Vietnamese-origin women. Feminist Criminology, 3(3), 191-215. doi: 10.1177/1557085108321500

Cantera-Espinosa, L. M. (2004a). Violencia en la pareja: Espejo del atropello, deconstrucción del amor. In L. M. Cantera-Espinosa (Ed.), La violencia a casa (pp. 113-140). Barcelona, Spain: Fundación Caixa Sabadell.
Cantera-Espinosa, L. M. (2004b). Más allá del género, nuevos enfoques de "nuevas" dimensiones y direcciones de la violencia en la pareja (Doctoral dissertation, Universidad Autónoma de Barcelona, Barcelona, Spain). Retrieved from http://www.tesisenred.net/TDX-1010105-171441

Castro, R., Casique, I., \& Bridis, C. (2008). Empowerment and physical violence throughout women's reproductive life in Mexico. Violence Against Women, 14(6), 655-677. doi: 10.1177/1077801208319102.

Castro, R., Peek-Asa, C., García, L., Ruíz, A., \& Kraus, J. F. (2003). Risks for abuse against pregnant Hispanic women: Morelos, Mexico and Los Angeles County, California. American Journal of Preventive Medicine, 25(4), 325-332.

Diekman, A. B., \& Eagly, A. H. (2000). Stereotypes as dynamic constructs: Women and men of the past, present, and future. Personality and Social Psychology Bulletin, 26, 1171-1188. doi: 10.1177/0146167200262001

Dill, K. E., \& Thill, K. P. (2007). Video game characters and the socialization of gender roles: Young people's perceptions mirror sexist media depictions. Sex Roles, 57(11-12), 851-864. doi: 10.1007/s11199-007-9278-1

Flood, M. (2011). Involving men in efforts to end violence against women. Men and Masculinities, 14(3), 358-377. doi: 10.1177/1097184X10363995

Gaceta Oficial del Distrito Federal. (2007). Decimaseptima época, 70. Retrieved from http://www.inmujer.df.gob.mx/work/sites/ inmujeres/resources/LocalContent/20/3/gaceta70_decreto.pdf

Gaceta Oficial del Distrito Federal. (2009). Reformas al código civil. Retrieved from https://anad1991.files.wordpress.com/2009/12/ parcial-gaceta-oficial-df-29-dic-2009-decreto-reformascodigo-civil.pdf

Gómez A. M., \& Speizer I. S. (2009). Intersections between childhood abuse and adult intimate partner violence among ecuadorian women. Maternal and Child Health Journal, 13(4), 559-566. doi: 10.1007/s10995-008-0387-4.

Gonzalez, B. (2006). Hacia la igualdad entre hombres y mujeres. Primera parte. Cambios, límites y problemas hoy. Pensamiento Crítico. Retrieved from http://www.pensamientocritico.org / bel-gon0306.html

Good, C., Aronson, J., \& Inzlicht, M. (2003). Improving adolescent's standardized test performance: An intervention to reduce the effects of stereotype threat. Journal of Applied Developmental Psychology, 24(6), 654-662. doi:10.1016/j.appdev.2003.09.002

Hamel, J. (2007). Domestic violence: A gender-inclusive conception. In J. Hamel \& T. L. Nicholls (Ed.), Family interventions in domestic violence: A handbook of gender-inclusive theory and treatment (pp. 3-26). New York, NY: Springer Publisher.

Hilton, J. L., \& Hippel, W. V. (1996). Stereotypes. Annual Review of Psychology, 47. Retrieved from http://www.questia.com/ googleScholar.qst;jsessionid=AFB4A3BD00A48D60218EB 46B442778F.inst3_3b?docId $=5000321907$

Hunnicutt, G. (2009). Varieties of patriarchy and violence against women. resurrecting "patriarchy" as a theoretical tool. Violence Against Women,15(5), 553-573. doi: $10.1177 / 1077801208331246$

Instituto Nacional de Estadística, Geografía e Informática (n.d.). Demografia y población. Retrieved from http://www.inegi.org. $\mathrm{mx} /$ Sistemas/temasV2/ Default.aspx?s=est\&c=17484

Instituto Nacional de Estadística, Geografía e Informática. (2000). Los jóvenes en México. México: Author. 
Instituto Nacional de Estadística, Geografía e Informática. (2003a). Encuesta nacional sobre la dinámica de las relaciones en los hogares. Retrieved from http://www.inegi.org.mx/ est/ contenidos/espanol/metodologias/encuestas/hogares/ dm_endireh03.pdf

Instituto Nacional de Estadística, Geografía e Informática. (2003b). Sistemas nacionales estadísticos y de información geográfica. México: Author.

Instituto Nacional de Estadística, Geografía e Informática. (2005). II conteo de población y vivienda. México. Retrieved from http://www.inegi.org.mx/prod_serv/contenidos/ espanol/ bvinegi/productos/geografia/publicaciones/delimex05/ DZMM_2005_0.pdf

Instituto Nacional de Estadística, Geografía e Informática. (2006). Encuesta nacional sobre la dinámica de las relaciones en los hogares. Retrieved from http://www.inegi.org.mx/ est/ contenidos/espanol/sistemas/endireh/2006/default. asp? $=11230$

Instituto Nacional de Estadística, Geografía e Informática. (2007). México en corto. Retrieved from http://www.inegi.gob.mx/ inegi/contenidos/espanol/prensa/Contenidos/estadisticas/ 2007/matrimonios07.pdf

Izquierdo, M. J. (2001). Sin vuelta de hoja: Sexismo, placer y trabajo. Barcelona, Spain: Bellaterra.

Krueger, J. I., Hasman, J. F., Acevedo, M., \& Villano, P. (2003). Perceptions of Trait Typicality in Gender Stereotypes: Examining the Role of Attribution and Categorization Processes. Personality and Social Psychology Bulletin, 29(1), 108-116. doi: 10.1177/0146167202238376

Krug, E., Dahlberg, L., Mercy, j., Zwi, A., \& Lozano, R. (2003). Informe mundial sobre la violencia y la salud. Organización Mundial de la Salud. Retrieved from http://whqlibdoc.who. int/publications/2002/9275324220_spa.pdf

Lee, Y. S., \& Hadeed, L. (2009). Intimate partner violence among Asian immigrant communities. Trauma, Violence, and Abuse, 10(2), 143-170. doi: 10.1177/1524838009334130

Lindhorst, T., \& Tajima, E. (2008). Reconceptualizing and operationalizing context in survey research on intimate partner violence. Journal of Interpersonal Violence, 23(3), 362-388. doi: 10.1177/0886260507312293

Mason, C. L., Kahle, J. B., \& Gardner, A. L. (1991). Drawa-scientist test: Future implications. School Science and Mathematics, 91(5), 193-198.

McHugh, M. C., \& Frieze, I. H. (2006). Intimate partner violence: New directions. Annals of the New York Academy of Science, 1087, 121-141. doi: 10.1196/annals.1385.011

McHugh, M. C., Livingstone, N., \& Frieze, I. H. (2008). Intimate partner violence: Perspectives on research and intervention. In F. L. Denmark \& M. A. Paludi (Ed.), Psychology of women: A handbook of issues and theories, (pp. 555-589). Westpor, US: Praeger Publishers.

Meza-de-Luna, M. E. \& Cantera, L. M. (2008). Relaciones de poder en eventos conflictivos en parejas. In E. García and J. López (Eds.), Actas de la conferencia Iberoamericana de investigación cualitativa 1, 175-187. Retrieved from http:// cehum.uab.es/docs/ActasIberacual2008.pdf
Meza-de-Luna, M. E. (2010). Estereotipos de Violencia en el conflicto de pareja. Construcciones y prácticas en una comunidad mexicana (Doctoral thesis, Universidad Autónoma de Barcelona, España). Retrieved from http:/www.tdx.cat/ TDX-0322111-154925

Nunnally, S.C. (2009). Racial homogenization and stereotypes: Black American college students' stereotypes about racial groups. Journal of Black Studies, 40(2), 252-265.

Okoye, U., \& Obikeze, D. (2005). Stereotypes and perceptions of the elderly by the youth in Nigeria: Implications for social policy. Journal of Applied Gerontology, 24(5), 439-452. doi: $10.1177 / 0733464805278648$

Ortega-Ceballos P. A., Mudgal, J., Flores, I., Rivera-Rivera, L., Díaz-Montiel, J.C., \& Salmerón, J. (2007). Determinantes de violencia de pareja en trabajadoras del IMSS Morelos. Salud Pública de México,49(5), 357-366. Retrieved from http:// redalyc.uaemex.mx/redalyc/ html/106/10649506/10649506. html

Plous, S., \& Williams, T. (1995). Racial stereotypes from the days of American slavery: A continuing legacy. Journal of Applied Social Psychology, 25(9),795-817.

Quelopana, A. M., Champion, J. D., \& Salazar, B. C. (2008). Health behavior in Mexican pregnant women with a history of violence. Western Journal of Nursing Research, 30(8),10051018. doi:10.1177/0193945908320464.

Ramírez-Rodriguez, J.C. (2006). Male violence against heterosexual partners: Facts and challenges. Review of Mexican literature. Salud Pública de México, 48(2), s315-s327.

Regan, K. V., Bartholomew, K., Kwong, M. J., Trinke, S. J., \& Henderson, A. J. (2006). The relative severity of acts of physical violence in heterosexual relationships: An item response theory analysis. Personal Relationships. 13(1), 37-52. doi: 10.1111/j.1475-6811.2006.00103.x

Rivera-Rivera, L., Lazcano-Ponce, E., Salmerón-Castro, J., SalazarMartínez, E., Castro, R., \& Hernández-Avila, M. (2004). Prevalence and determinants of male partner violence against Mexican women: A population based study. Salud Pública de México, 46(2), 113-122. doi: http://dx.doi.org/10.1590/ S0036-36342004000200005

Sánchez-Jiménez, B., Hernández-Trejo, M., \& Lartigue-Becerra, T. (2008). Violencia conyugal y depresión durante el embarazo. Salud Pública de México, 50(5), 353-354. doi: http://dx.doi. org/10.1590/S0036-36342008000500004

Saunders, D. (1988). Wife abuse, husband abuse, or mutual combat?: A feminist perspective on the empirical. In K. Yllo \& M. Bograd (Eds.), Feminist perspectives on wife abuse (pp. 90113). Newbory Park, California: Sage Publications.

Schultz, K. (2006). Gender beliefs and the meaning of work among Okinawan women. Gender and Society, 20(3),382-401. doi: $10.1177 / 0891243206286727$

Seelau, S. M., \& Seelau, E. P. (2005). Gender-role stereotypes and perceptions of heterosexual, gay and lesbian domestic violence. Journal of Family Violence, 20(6), 363-371. doi: 10.1007/ s10896-005-7798-4

Spencer, S. J., Steele, C. M., \& Quinn, D. M. (1999). Stereotype threat and women's math performance. Journal of Experimental Social Psychology, 35(1), 4-28.

Steinmetz, S.K. (1977). The battered husband syndrome. Victimiology, 2(3-4), 499-509. 
Straus, M. (1979). Measuring intrafamily conflict and violence: The conflict tactics (CT) scales. Journal of Marriage and the Family, 41(1), 75-88.

Tellez, M. (2008). Community of struggle: Gender, violence, and resistance on the US/Mexico border. Gender and Society, 22(5), 545-567. doi: 10.1177/0891243208321020
Toneli, M. J. F., Lago, M. C. S., Beiras, A., \& Clímaco, D. A. (2010). Atendimento a homens autores de violência contra as mulheres: Experiências latino americanas. Florianópolis: UFSC/CFH/NUPPE.

Recebido em 11.09.2013

Primeira decisão editorial em 18.04.2016

Versão final em 15.05.2016

Aceito em 27.06.2016 